\title{
Edmund Husserl's Critique of European Science: A Philosophical Evaluation of Covid-19 Pandemic
}

\section{Sunday Chukwuma Ezeani ${ }^{1}$, Ignatius Nnaemeka Onwuatuegwu ${ }^{2}$}

\author{
1Philosophy Department, Bigard Memorial Seminary Enugu, Nigeria \\ 2Department of Philosophy, Faculty of Arts, Nnamdi Azikiwe University Awka, Nigeria \\ E-mail: sunnydemajesty@gmail.com; in.onwuatuegwu@unizik.edu.ng
}

${ }^{*}$ Corresponding Author: Sunday Chukwuma Ezeani

\begin{abstract}
The whole world today is dumped deeply and hopelessly into the scourge of COVID-19 Pandemic. That the invisible virus has kept the entire world both developed and developing countries standstill has busted contemporary man's bravado in his scientific and technological achievements. This pandemic has called man to look inward into his very existence. The pandemic inasmuch it has brought untold sufferings, is not without some positive influences. It is a time like this, that philosophical reflection on history is of paramount importance. Lest we forget, COVID-19 is not the first pandemic in the human history. There were Black Death of 1346-1353, Spanish Flu of 1918, HIV/AIDS pandemic (at peak 2002-2005), and others. The novel COVID-19 is the child of our time and so we are compelled to live with its challenges both now and after. Nevertheless, in this philosophical reflection, we are going to look into the work of Edmund Husserl, The Crisis of European Sciences and Transcendental Phenomenology and extract what its contributions signify to our time. Husserl wrote during the postwar years in Europe and so like most of philosophers argued that Europe was not suffering political crisis but crisis of civilization. Naturalism and positivism were the ideologies that were reigning, thus denigrating the status of philosophy in searching into ultimate and highest questions that bother on the vital need of man that is the question of meaning or meaninglessness of human existence (Heffernan; 2015). It is in this frame of thought that we are going to survey the history of Covid19 pandemic, the conspiracy theories on its origin and evaluate the implications of the pandemic in the post-Covid19 society. This essay attempts to inspire a critical reflection on the reader to look at the condition of our time with a critical and philosophical hope and faith.
\end{abstract}

Keywords: Covid-19; Conspiracy theories; Bill Gates Scapegoat; Biological Warfare; Crisis of European Science

\section{INTRODUCTION}

A novel Coronavirus called SARS-CoV2 has attracted considerable attention in the past six months, unlike its sisters the Middle East Respiratory Syndrome (MERS) and Severe Acute Respiratory Syndrome (SARS), and the disease it causes has been termed "Coronavirus disease 2019" (COVID-19). The current indications show that SARS-CoV2 is transmitted through bats mainly. These viruses pose threats to the human respiratory system, and thus, people with lung damage or respiratory problems are more susceptible to being infected by these viruses (Abaido \& Takshe; 2020).

Coronavirus disease 2019 has really affected virtually all the continents of the World. China, Italy and America remain the major places where death patients ran in thousands. Nigeria announced her first confirmed case of COVID-19 on 27 February, 2020 when an Italian citizen living in Lagos was tested positive for the virus. Also, on 9 March, 2020, a second case of the virus, a Nigerian citizen was reported in Ewekoro, Ogun state. As at 3 June, 2020, The Nigeria Center for Disease Control (NCDC) reported; 11,166 cases have been confirmed, 3,329 cases have been discharged, and 315 deaths have been recorded in 35 states and the Federal Capital Territory. Only Cross River state has not recorded a confirm case in Nigeria (Internet source; 2020).

Until now the World Health Organization has reported that there is no vaccine and therapeutic solution for the virus. But some technical advice has been giving on how to prevent the contamination of the virus like social distancing, continuous and constant washing of hands, sanitizing of hands and wearing of facemask. The nonpharmaceutical measure, social distancing has been noted to contribute maximally in reduction of the kinetic rate of the virus among the populace in many countries (Komaroval \& Wodarz). The virus has led to total lockdown of religious, economic, educational and social institutions. And most importantly, it is projected that the virus will have both negative and positive impact in life of the people all over the world. We shall discuss the impacts later in this study. 


\section{COVID-19: A PANDEMIC}

Pandemic is derived from the Greek words Pan- all and demos- people, literally it means all people. A pandemic is defined as an "epidemic occurring worldwide, or over a very wide area, crossing international boundaries and usually affecting a large number of people" (Last; 2001). WHO defined pandemic as a worldwide spread of a new disease. Some pandemics in the world history are plague of Justinian (AD. 541-542), Black death (13-15 century), small pox (1520-1527), Cholera (1829-1851), Influenza (1918-1919) and HIV/AIDS (1981/2006) (Kilbourne; 2008).

World Health Organization has declared the coronavirus disease a pandemic. However, most people think that once a disease is declared a pandemic, then it signifies that the disease is a fatal disease. But from the definitions above, we see that the underlying thing about pandemic is its global range of spreading and affecting many people. COVID-19 has almost affected all the continents of the world and so it is rightly called a pandemic. Calling this outbreak, a pandemic signifies to everyone that we all in this together, fighting a common enemy (Lee; 2020).

\section{EXPLICATIONS OF SOME CONSPIRACY THEORIES ON THE ORIGIN OF COVID-19}

The question of the origin of the coronavirus has been shrouded in mystery. Thus, there are many conspiracy theories, all attempting to explain the origin of the novel Coronavirus. Alliance for Science (AS), an online website reports ten conspiracy theories. Among other things AS reports; "As the COVID-19 crisis worsens, the world also faces a global misinformation pandemic. Conspiracy theories that behave like viruses themselves are spreading just as rapidly online as SARS-CoV-2 does offline" (Lynas; 2020). We shall however elucidate just few of the conspiracy theories below.

\section{Blaming 5G}

This conspiracy theory alleges that the spread of COVID-19 is worsened by $5 \mathrm{G}$ network. However, this conspiracy theory could be debunked on account that it is biologically impossible for viruses to spread using the electromagnetic spectrum. The latter are waves/photons, while the former are biological particles composed of proteins and nucleic acids (Internet source; 2020). This could be invalidated with the philosophical principle of mind-body relationship. In the argument of mind and body relationship, the contending question is, how can the body (material) influence the soul (spirit)? However, in a more emphatic manner WHO warns that viruses cannot travel on mobile networks, and that COVID-19 is spreading rapidly in many countries that do not have 5G -networks. This conspiracy theory (Internet source; 2020) is built on the fallacy of false cause. Because the virus spread within the time of mounting of $5 \mathrm{G}$, the proponents concluded that the $5 \mathrm{G}$ caused COVID-19.

\section{Bill Gate Scapegoat}

This conspiracy theory hangs on the fallacy of false assumption, whereby some people link Bill Gate's postulation in the 2015 TED conference in Vancouver with the origin of COVID-19. Gate warned; "If anything kills over 10 million people over the next few decades, it is likely to be a highly infectious virus rather than war." Some allege that Gate has a secret knowledge of the origin of the virus. Thus, they accuse him of making vaccines mandatory, or even attempting to implant microchips into the people (Wakefield; 2020).

\section{The Virus Escaped from a Chinese Lab}

This conspiracy theory has led to political and ideological conflict between China and USA. The proponents of this view hold that the virus originated from Chinese virology Institute in Wuhan where researchers have been studying bat coronaviruses for a long time. However, concerned researcher in the institute, Shi Zhengli, a prominent virologist who spent years collecting bat dung samples in caves and was a lead expert on the earlier SARS outbreak, reported that following genetic sequencing that there is no connection between COVID-19 and the viruses sampled and studied in the Wuhan Institute of Virology by her team (Lynas; 2020).

\section{Coronavirus as Biological warfare}

Some people hold that China intentionally engineered the virus for biological warfare. Donald Trump and Tom Cotton are major proponents of this theory. Trump calls the virus, "Chinese virus". However, Tom Cotton in his Twitter page on 17 February, 2020 disclaimed the accusations of some people that he said that coronavirus is an engineered bio weapon. He however enumerated four hypotheses about the origin of the virus:

i. $\quad$ Natural (still the most likely, but almost certainly not from the Wuhan food market)

ii. Good science, bad safety (e.g., they were researching things like diagnostic testing and vaccines, but an accidental breach occurred).

iii. Bad science, bad safety (this is the engineered bioweapon hypothesis, with an accidental breach)

iv. Deliberate release (very unlikely, but shouldn't rule out till the evidence is in)

He then concludes that these are not "theories" and certainly not conspiracy theories". They are hypotheses that ought to be studied in the light of the evidence, if the Chinese Communists Party would provide. 


\section{THE SYNTHESIS OF THE CONSPIRACY THEORIES}

Tom Cotton made a very important claim that calls for more critical and indiscriminate investigation into the origin of COVID-19. The origin of COVID-19 is mired deeply in mystery on account of political game. Hence, getting clearer and truer origin of the virus might be very difficult. Nevertheless, from the nuances of the different conspiracy theories or hypotheses, we can project that the origin of the virus has both scientific and technological and political undertone. In the theories, we observe in the thread of their configurations some unfortunate and obvious syncretic manipulation of the powers of science and politics.

It is in this regard that we are going to make a philosophical appraisal of the phenomenon of COVID-19 pandemic. The disease as we will show is symptomatic of the crisis of science and politics in our era which is anchored on the substitution of rationality with irrationality in the two fields (science/technology and politics).

We are going to deploy Husserl's thoughts on Crisis of European Science in our discussion. Thus, the next session will give a succinct account of Husserl's thought.

\section{A SYNOPTIC EXPLICATION OF HUSSERL'S THE CRISIS OF EUROPEAN SCIENCE}

Edmund Husserl was born of Jewish parents in the Moravian province of Prossnitz in 1859, the same year in which Bergson and Dewey were born. Husserl was motivated to philosophizing by his quest for certainty. However, this essay is concerned with his last major work, The Crisis of European Science which was published in 1936. Husserl was so much concerned with phenomenology which is the science of experience. To understand the reason Husserl embarked on Phenomenology, we need to know the starting point of his philosophical enterprise. Hence, Stumpf and Fiesser reports;

His philosophy grew out of his deep conviction that Western culture had lost its true direction and purpose. His attitude is reflected in the title of his last major philosophical work, Crisis of European Sciences (1936). The "crisis" consists of philosophy's departure from its true goal, which is to provide the best possible answers to human concerns, to deal rigorously with our quest for the highest values, and, in short, to develop the unique, broad-range capacities of human reason. He described the "crisis" as the "seeming collapse of rationalism," and he set his lifetime objective as "saving human reason" (Stumpf \& Fieser).

Husserl's subtitle, "The Crisis of the Sciences as Expression of the Radical Life-Crisis of European Humanity" shows that he set out to dig up the fundamental problem of the social life of the people. He reflects that "natural sciences rest on the fatal prejudice that nature is basically physical. On this view, the realm of spirit- that is human culture- is causally based on physical things, which ultimately threaten our conception of knowing, valuing and judging" (Stumpf \& Fieser).

The natural science which is built on naturalism, that is the reduction of everything to physical reality, has neglected or cannot handle the ultimate question of human existence. In this regard, Husserl decries; "The exclusiveness with which the total world-view of modern man, in the second half of the nineteenth century, let itself be determined by the positive sciences and be blinded by the "prosperity" they produced, meant an indifferent turning-away from the questions which are decisive for a genuine humanity"(Husserl; 1970). The questions are not mere scientific questions that deal with 'how' rather they are philosophical questions that anchor on the 'why' of human existence.

He noted that fact-minded science produces fact-minded people. In this regard, positive science which has a one-dimensional understanding of reality as mere matter or physics has constituted a menace to the humanity. It is worthy to note that Husserl wrote the Crisis within the postwar years and so he experienced the incapacity of scientific development to solve the basic human problem, which is the problem of human existence. Thus, he never minced words in saying;

In our vital need-so we are told-this science has nothing to say to us. It excludes in principle precisely the questions which man, given over in our unhappy times to the most portentous upheavals, finds the most burning: questions of the meaning or meaninglessness of the whole of this human existence. Do not these questions, universal and necessary for all men, demand universal reflections and answers based on rational insight? (Husserl; 1970).

Husserl accounts that natural science has lost its philosophical root. Philosophy on its part has taken a wrong path. And so, he argues that philosophy has to return to its root, which is the study of being as being. It deals with ultimate question of being. Husserl challenges philosophers to go back to the early Greek (Plato and Aristotle) understanding of philosophy. In this vein, Stumpf and Fieser elucidate:

Greek philosophers then entered the picture with a new kind of outlook, namely, a universal critique of all life and its goals. The positive side of this critique was its aim of elevating people through universal reason toward a new humanity, rising above the limited horizons of custom, geography, and social groups. What made this possible was a new conception of truth. This truth was independent of tradition, universally valid, and capable of infinite refinement. Here, then, is the origin of the spiritual life and the culture of Europe. The systematic formulation of this attitude is what the Greeks called philosophy (Stumpf \& Fieser). 
Therefore, philosophy deals with rationality and consequently with truth. This is elaborated in the words of Husserl, thus;

To be human at all is essentially to be a human being in a socially and generatively united civilization; and if man is a rational being (animal rationale), it is only insofar as his whole civilization is a rational civilization, that is, one with a latent orientation toward reason or one openly oriented toward the entelechy which has come to itself, become manifest to itself, and which now of necessity consciously directs human becoming. Philosophy and science would accordingly be the historical movement through which universal reason, "inborn" in humanity as such, is revealed (Husserl; 1970).

From the above statement, we ask; to what extent is the practice of science and technology in our age rational? Can we see this rationality even in our politics? Is COVID-19 pandemic not symptomatic of irrationality inherent in our age? While Husserl argues that the crisis of European humanity is crisis of science which is anchored on the incapacity of science and philosophy to aid man to answer the vital question of human existence; can this be said of our age in the COVID-19 pandemic? Can we say that our age is a rational civilization when human life is caricatured?

\section{THE IMPLICATION OF HUSSERL'S CRISIS OF EUROPEAN SCIENCE ON COVID-19 PANDEMIC}

In our discussion of the different conspiracy theories, we argued that though the theories could not accurately give us the account of the origin of the virus. We note that the conspiracy theories show us the crisis of science/technology and politics. As Husserl revealed the crisis of Europe is a crisis of civilization. That means a civilization that is bereft of rationality and truth.

In the Crisis of European Science, Husserl showed that science has not adequately aided man to answer the basic question of the meaning of human existence. In this same vein, we also note with great disappointment that scientists have not given us sufficient account of the origin of the COVID-19. Its origin is still shrouded in mystery and political manipulation. And amidst this, human life is heavily endangered.

We also see that Husserl's famous critique of the "life-world" holds that the European sciences have lost touch with everyday life, in their zeal for "mathematizing" nature. The result is a disastrous loss of respect for rationality in ordering human life, from science to politics (Smith; 2007). Loss of rationality in politics is boldly evidenced in Nigeria. Our political leaders seem to be playing politics with the pandemic. The Nigeria Center for Disease Control (NCDC) and the government are not transparent and sincere in their statistics. Consequently, most of the masses do not trust the government.

The way the issue of COVID-19 is treated in Nigeria reflects what Husserl argues, that "merely fact-minded sciences make merely fact-minded people." Our government and the Nigeria Center for Disease Control have always been giving us mere number of cases. This bespeaks dehumanization, when human beings in a deadly situation like this are merely reduced to numerical facts. The government has not shown us concretely how they are managing the health of the confirmed cases. Rather the NCDC is solely concerned with publicizing the number of confirmed cases, discharged and death, as if it is a livescore website.

Finally, the COVID-19 pandemic is symptomatic of the underlying crises of science/technology and politics in our era. Like Husserl argues that the crisis of European science is the crisis of European civilization; ours is the crises of politics and science. Our scientists and politicians are bereft of rationality and quest for truth. It is only on the two wings of rationality and truth that they (scientists and politicians) can appreciate our common humanity and imbibe culture of life instead of culture of death.

\section{LIVING WITH THE SCARS AND LESSONS OF COVID19: A PHILOSOPHICAL EVALUATION}

Like every Pandemic, COVID-19 is really affecting the humanity in a negative manner. There has been total lockdown of economic sectors, religious institutions, schools, transportation and so on. The pandemic has enormous impacts in our world. In this section, we shall outline the scars and lessons of COVID-19; we shall approach this with philosophical openness and hope.

\section{Scars of COVID-19}

\section{- Economic Scar}

The economy of many countries has been affected. Nigeria has been in economic comatose, after the pandemic we may experience economic death if proper and proactive measures are not taking. , Tobilola Ogunpolu, a senior economic analyst, reports; "Industrial facilities have been shut down in some affected countries, and the global supply chain has been disrupted. Brent crude prices have fallen below $\$ 22$ per barrel- the lowest since 2003- due to the escalating global economic impact of the COVID-19 pandemic and the price war between Saudi Arabia and Russia. Nigeria, the most populous country in Africa, is awakening to the new economic and social reality as a result of the COVID-19 crisis" (Ogunpolu; 2020). It is projected that there will be high rate of unemployment, poverty and so on during and after the pandemic. 


\section{- Psychological Scar}

Some people are really affected not by the pandemic but panic of the COVID-19. Many people are psychologically weighed down on account of the COVID-19 crisis. American Psychological Association reports; "The coronavirus pandemic is an epidemiological and psychological crisis. The enormity of living in isolation, changes in our daily lives, job loss, financial hardship and grief over death of loved ones has the potential to affect the mental health and well-being of many" (Internet source; 2020). Hence, there is possibility of some people relapsing to anxiety, panic attacks, depression and suicide.

\section{- Social scar}

The pandemic has really affected the very thread of African existence which is communality and solidarity. These are well expressed in the funeral ceremonies, traditional wedding and religious activities. However, with emphasis on social distancing in order to curtail the increase of the spread of the virus, the social reality of African people has been negatively affected. It is believed that during the post-COVID-19 ere there is possibility that the rate of social gathering and interaction will be reduced.

\section{- Religious Scar}

Africans are noted for their religiousity, this is manifested by their religious activities like going to Church, holding night crusades. However, with the pandemic religious institutions have been closed and the people are really concerned that their very source and summit of existence is denied of them. Inasmuch as, the virus has dealt a heavy blow on the excessive religiousity of our people, it has really instigated our people to deepen their spirituality which is not restricted to religious externalism and rituals.

\section{Lessons of COVID-19}

\section{- Common Humanity}

The pandemic really calls our attention to the common root of our human existence. And thus, we must learn the lesson of humanity from the virus. That the virus affects almost all the continents and nations of the world, the poor and the rich, white and black, reminds us that we all are human beings. It calls us to inter-subjectivity and solidarity. We should treat people as 'thou' and not 'it'. The case of killing of George Floyd on account of racial discrimination, which occurred during the pandemic at Minneapolis showcased that we have not learnt the lesson of our common humanity.

\section{- Alternative Mode of Existence}

The COVID-19 pandemic has taught us other alternatives of doing things. This is well expressed in area of education. Many institutions in Nigeria have embarked on e-learning. However, inasmuch as our country does not have basic facility like network and electricity, the e-learning has shown an alternative way of education. The post-COVID-19 Nigeria will definitely sustain this mode of education.

\section{- The Value of life}

The COVID-19 has really taught us the value of human life. That we survived the longtime of lockdown without social, religious and educational activities, shows us that the sacredness of life. Everything might have been locked down but human life is not. And so, Dennis Snower reveals:

The Coronavirus shows us how terrible it really is to waste our lives, embroiled in endless battles for wealth and status and power. How terrible it really is not to recognize the value in the people around us - not just colleagues and fellow citizens, but also complete strangers. How terrible it is not to give our lives meaningevery day- by honouring the sacredness of life and according all living things the respect, sensitivity and care that they deserve (Snower; 2020).

\section{EVALUATION AND CONCLUSION Evaluation}

In our research, we observe how the conspiracy theories on the origin of the pandemic reveal the crisis of science and politics in the world. In line with Edmund Husserl, we argue that the substitution of rationality with irrationality has led our science and politics to be bereft of truth which recognizes our common humanity and so leads to rational civilization. The current situation of the Pandemic shows that anthropological question is taken for granted. This was actually what motivated Husserl to write the Crisis of European Science and thus prescribing that science like philosophy in the Ancient era of Plato and Aristotle should be concerned with the vital question of the meaning of human existence. Politics and science should help in the actualization of human development but the current manipulation of COVID-19 pandemic by science and politics puts a big question mark on the two wings of human civilization- science and politics.

\section{Conclusion}

We suggest that the politicians and scientists should adopt the philosophical attitude of critical inquiry into ultimate causes. This attitude goes beyond fact-minded science and technology to value-minded science and politicking. Fact-minded science which is prevalent in our cotemporary era studies sciences for science sake. However, science and technology that is value-oriented incorporates the question of the meaning of human existence in its inquiry, research and innovation. Our politicians adopting this attitude also will be transparent and humane in the handling of COVID-19 crisis. 


\section{REFERENCES}

[1] Heffernan, G. (2015) "Chapter 17 Phenomenology Is a Humanism: Husserl's Hermeneutical-Historical Struggle to Determine the Genuine Meaning of Human Existence in The Crisis of the European Sciences and Transcendental Phenomenology", Springer Science and Business Media LLC.

[2] Abaido, G. M. and Takshe, A. A. (2020) "COVID-19: Virus or Viral Conspiracy Theories?", American Journal of Biomedical Science and Research, 8(2): 112.

[3] Covid 19, www.ncdc.gov.ng accessed June, 2020.

[4] Komaroval, N. L. and Wodarz, D. "Patterns of the COVID 19 epidemic spread around the world: exponential vs power laws", 2.

[5] Last, J. M. ed. (2001) "A Dictionary of Epidemiology", Oxford University Press, New York.

[6] Kilbourne, E. D. (2008) "Plagues and pandemics: past, present, and future", in Nick Bostrom and Milan M. Cirkovie Ed's., Global Catastrophic Risk, Oxford University Press, New York: 290.

[7] Lee, B. Y. (2020) "The COVID-19 Corona virus Is Now A Pandemic: What Does That Mean?" www.forbes.com accessed 1o June, 2020.

[8] Lynas, M. (2020) "COVID: Top 10 current conspiracy theories", www.allianceforscience.cornell.edu accessed 11 June, 2020.

[9] Wakefield, J. (2020) "How Bill Gates became the voodoo doll of Covid conspiracies", BBC News, 5 June, www.bbc.com (accessed 10 June, 2020).

[10] Lynas, M. (2020) Op.cit

[11] Stumpf, S. E. and Fieser, J. (2012) "Philosophy: a Historical Survey with Essential Readings", McGraw-Hill Education, New York, 456.

[12] Ibid. $456-457$

[13] Husserl, E. (1970) "The Crisis of European Sciences and Transcendental Phenomenology", trans. David Carr, Northwestern University Press, Evanston, 5.

[14] Ibid. 5 - 6.

[15] Stumpf, S. E. and Fieser, J. (2012) Ibid. 457.

[16] Husserl, E. (1970) Ibid. 15-16.

[17] Smith, W. D. (2007) "Husserl", Routledge, New York, 4.

[18] Ogunpolu, T. (2020) "From Pandemic to Poverty: Nigeria's Future with COVID-19, www.nairametrics.com (accessed 11 June, 2020).

[19] Psychological impact of COVID-19 www.apa.org_(accessed 11 June, 2020).

[20] Shower, D. J. (2020) "Fundamental Lessons From the COVID-19 Pandemic, www.global-solutioninitiative.org (accessed 11 June, 2020). 